\title{
Redesain Kewenangan Mahkamah Konstitusi dalam Penyelesaian Sengketa Perselisihan Hasil Pemilihan Umum Presiden dan Wakil Presiden di Indonesia
}

\author{
Harry Setya Nugraha \\ Mahasiswa Pascasarjana Fakultas Hukum Universitas Islam Indonesia \\ Jl. Cik Di Tiro No. 1 Yogyakarta \\ harrysetyanugraha@ymail.com
}

\begin{abstract}
The implementation of Presidential election in Indonesia cannot be regarded as democratic since the design of dispute settlement of the Presidential Election by the Constitutional Court is not planned ideally. Thus, this study examines some research problems underlying the issue: first, what is the urgency of redesigning the authority of the Constitutional Court in resolving disputes of Presidential Election in Indonesia? and second, how is the ideal concept of dispute settlement in order to achieve a democratic election? The method used in this research is normative juridical of legislation approach and concept approach. The result of the study revealed that: first, it is highly urgent to redesign the authority of the Constitutional Court in the dispute settlement of PHPU of President and Vice President in Indonesia to democratize the election as well to find alternative solutions to the elections that could provide legal certainty, fairness and expediency. Second, redesigning the authority of the Court in resolving disputes of the Presidential PHPU includes the expansion of the definition of disputed election results; designing the benchmark of structured systematic and massive electoral violations; and redesigning the time given by the Court in resolving electoral disputes.
\end{abstract}

Keywords: Presidential election, Redesign, dispute, the constitutional court.

\begin{abstract}
Abstrak
Penyelenggaraan pemilu Presiden dan Wakil Presiden di Indonesia belum dapat dikatakan berjalan secara demokratis. Hal ini dikarenakan belum idealnya desain penyelesaian sengketa Presiden dan Wakil Presiden oleh Mahkamah Konstitusi. Penelitian ini mengkaji permasalahan: pertama, apa urgensi dilakukannya redesain kewenangan MK dalam menyelesaikan sengketa Presiden dan Wakil Presiden di Indonesia? dan kedua, bagaimana konsep ideal dalam penyelesaiannya agar terwujudlah pemilu yang demokratis? Metode penelitian yang digunakan yaitu yuridis normatif dengan pendekatan perundang-undangan dan pendekatan konsep. Hasil penelitian menyimpulkan bahwa: pertama, urgensi dilakukannya redesain terhadap kewenangan MK dalam penyelesaian sengketa PHPU Presiden dan Wakil Presiden di Indonesia untuk mendemokratiskan pemilu serta sebagai bentuk ikhtiar menemukan alternatif solusi terhadap pemilu yang dapat memberikan kepastian hukum, keadilan dan kemanfaatan. Kedua, redesain kewenangan MK dalam penyelesaian sengketa PHPU Presiden dan Wakil Presiden meliputi perluasan makna sengketa hasil pemilu; mendesain tolak ukur pelanggaran pemilu yang bersifat terstruktur, sistematis, dan masif; dan mendesain ulang waktu yang diberikan oleh MK dalam menyelesaikan sengketa pemilu.
\end{abstract}

Kata Kunci: Pilpres, redesain, PHPU, mahkamah konstitusi 


\section{Pendahuluan}

Pemilihan umum (pemilu) merupakan suatu keniscayaan politik untuk membentuk pemerintahan yang demokratis. Bahkan di kebanyakan negara demokrasi, pemilu dianggap lambang sekaligus tolak ukur dari demokrasi itu sendiri. ${ }^{1}$ Hal ini dikarenakan bahwa pemilu merupakan wujud nyata dari implementasi demokrasi. ${ }^{2}$ Dengan kata lain, pemilu merupakan konsekuensi logis dianutnya prinsip demokrasi.

Akan tetapi yang perlu diketahui, bahwa meskipun pemilu merupakan wujud nyata implementasi demokrasi, tidak semua pemilihan bersifat demokratis. ${ }^{3}$ Oleh karenanya, pemilu sebagai salah satu aspek demokrasi juga harus diselenggarakan secara demokratis. Pemilu yang demokratis bukan hanya sekedar lambang, tetapi pemilu yang demokratis haruslah kompetitif, berkala, inklusif (luas), dan definitif. 4

Merloe mengatakan, bahwa salah satu ukuran dari suatu pemilu diselenggarakan secara demokratis atau tidak adalah terbangunnya kepercayaan masyarakat terhadap pemilu yang menghasilkan pemerintahan yang legitimate. Berkaitan dengan hal tersebut, kepercayaan masyarakat terhadap pemilu sehingga menghasilkan pemerintahan yang legitimate akan dengan sendirinya terbangun manakala tidak terjadi pelanggaran dan permasalahan terhadap hasil daripada pelaksanaan pemilu. Kalaulah kemudian terjadi kemungkinan adanya pelanggaran-pelanggaran pemilu dan perselisihan hasil pemilu, hal tersebut mampu diselesaikan secara demokratis dan proporsional melalui mekanisme hukum agar pemilu tetap legitimate. Terkait hal ini, Mahkamah Konstitusi (MK) hadir sebagai lembaga peradilan yang memiliki kewenangan untuk memutuskan dalam tingkat pertama dan akhir yang putusannya bersifat final untuk memutus perselisihan tentang hasil pemilihan umum (PHPU) sebagaimana termuat dalam Pasal 24C perubahan ketiga Undang-Undang Dasar Negara Republik Indonesia Tahun 1945 (UUD NRI 1945). hlm. 94.

${ }_{1}$ Miriam Budiarjo, Dasar-Dasar Ilmu Politik, edisi Revisi, PT. Gramedia Pustaka Utama, Jakarta, 2008,

\footnotetext{
${ }^{2}$ Muktie Fadjar, Pemilu: Perselisihan Hasil Pemilu dan Demokrasi, Setara Press, Malang, 2003. Hlm. 1

${ }^{3}$ Ibid., hlm. 28

${ }^{4}$ Ibid
} 
Namun sangat disayangkan selama perjalanannya, masih terdapat permasalahan berkenaan dengan electoral process pada diri MK dalam penyelesaian pelanggaran penyelenggaraan pemilu. Hal tersebut membuat MK belum mampu memainkan perannya dengan baik dalam menyelesaikan perselisihan hasil pemilu, terlebih khusus adalah pemilu Presiden dan Wakil Presiden. Di samping itu, juga membuat pemilu yang berlangsung di Indonesia kini belum sepenuhnya berjalan secara demokratis.

Beberapa permasalahan terkait electoral process sebagaimana dimaksud meliputi: pertama, sempitnya pemaknaan frasa "hasil pemilu" yang hanya dimaknai sebagai "perselisihan mengenai penetapan hasil pemilu yang dilakukan secara nasional oleh KPU". Sempitnya pemaknaan frasa "hasil pemilu" tersebut membuat MK kini disebut-sebut hanya sebagai "mahkamah kalkulator" dalam hal penyelesaian terhadap sengketa PHPU, bukan lagi MK yang berfungsi mengawal demokrasi (the guardian of the democracy), termasuk mengawal asas-asas pemilu yaitu "Langsung, umum, bebas, rahasia dan adil" (Luber dan Jurdil) yang tercantum dalam Pasal 22 E ayat (1) UUD NRI 1945.

Kedua, tidak adanya tolak ukur yang dapat digunakan hakim sebagai acuan dalam membuktikan unsur-unsur "Terstruktur, Sistematis dan Masif (TSM)", dalam pembuktian persidangan perselisihan hasil pemilu Presiden dan Wakil Presiden. Hal ini membuat tafsir "TSM" tersebut menjadi "liar" dan berimplikasi pada perbedaan dasar pertimbangan bagi setiap hakim dalam memutus perkara di MK.

Ketiga, mengenai terbatasnya waktu yang diberikan undang-undang kepada MK untuk menyelelesaikan perkara perselisihan hasil pemilu Presiden dan Wakil Presiden, yakni hanya 14 hari. Terbatasnya waktu tersebut membuat masyarakat pencari keadilan tidak mungkin hanya menggantungkan keadilan atas berjalannya demokrasi dan pemilu kepada MK..$^{5}$ Inilah yang membuat PHPU Presiden dan Wakil Presiden yang idealnya bukan perkara yang sederhana dalam arti tingkat kompleksitas masalahnya, terkesan menjadi perkara yang sederhana dan cepat karena time-frame penyelesaiannya sangat singkat.

${ }^{5}$ Ni'matul Huda, Penyelesainan Sengketa Pemiliban Umum 2014 di Mabkamah Konstitusi, Proshiding Seminar dan Lokakarya Evaluasi Penyelenggaraan Pemilihan Umum Legislatif Tahun 2014 di Indonesia, PSHK, Yogyakarta, 2014. hlm 90 


\section{Rumusan Masalah}

Berdasarkan uraian dari latar belakang masalah di atas, dapat dirumuskan beberapa permasalahan sebagai berikut. Pertama, mengapa perlu dilakukan redesain terhadap kewenangan Mahkamah Konstitusi dalam penyelesaian sengketa perselisihan hasil pemilihan umum Presiden dan Wakil Presiden di Indonesia? Kedua, bagaimana konsep ideal penyelesaian sengketa perselisihan hasil pemilihan umum Presiden dan Wakil Presiden Indonesia?

\section{Tujuan Penelitian}

Adapun penelitian ini bertujuan untuk mengetahui: pertama, urgensi dilakukan re-desain terhadap kewenangan Mahkamah Konstitusi dalam penyelesaian sengketa perselisihan hasil pemilihan umum Presiden dan Wakil Presiden di Indonesia; kedua konsep ideal penyelesaian sengketa perselisihan hasil pemilihan umum Presiden dan Wakil Presiden Indonesia.

\section{Metode Penelitian}

Jenis penelitian ini adalah penelitian hukum normatif. Sumber data yang digunakan adalah sumber data sekunder yang terdiri dari bahan hukum primer; bahan hukum sekunder; dan bahan hukum tersier. Penelitian ini dianalisis secara deskriptif kualitatif, yakni mengumpulkan dan menyeleksi bahan hukum sesuai dengan permasalahan yang diteliti, kemudian dideskripsikan sehingga menghasilkan gambaran atau kesimpulan yang sesuai dengan keadaan sebenarnya sehingga mampu menjawab seluruh permasalahan yang ada. Sementara dalam hal pendekatan hukum, penelitian ini menggunakan 2 (dua) model pendekatan. Pertama, pendekatan perundang-undangan karena bahan utama yang akan dianalisis adalah UU tentang MK dan UU tentang Pemilu. Kedua, pendekatan konsep karena salah satu bagian dari penelitian ini nantinya akan dimulai dengan mengidentifikasi prinsip-prinsip atau pandangan doktrin yang sudah ada untuk kemudian memunculkan gagasan baru. 


\section{Hasil Penelitian dan Pembahasan}

\section{Konsepsi Demokrasi dan Pemilu Demokratis}

Sejarah tentang paham demokrasi itu menarik, sedangkan sejarah tentang demokrasi itu sendiri menurut Held sangatlah membingungkan. ${ }^{6}$ Ada sebuah fakta menarik tentang demokrasi itu sendiri. Di zaman modern ini, hampir semua negara mengklaim menjadi penganut paham demokrasi.7 Padahal dahulunya, di zaman Yunani Kuno istilah demokrasi itu mempunyai konotasi yang sangat buruk. Demokrasi (demos+cratos atau demos + kratien) dibayangkan orang sebagai pemerintahan oleh semua orang yang merupakan kebalikan dari konsep pemerintahan oleh satu orang (autocracy). ${ }^{8}$

Demokrasi menurut asal kata berarti "rakyat berkuasa" atau "government or rule by the people". Dalam bahasa Yunani, demos berarti rakyat, kratos/kratein berarti kekuasaan/berkuasa. ${ }^{9}$ Artinya kekuasaan itu pada pokoknya diakui berasal dari rakyat sehingga rakyatlah yang sebenarnya menentukan dan memberi arah serta yang sesungguhnya menyelenggarakan kehidupan kenegaraan. Keseluruhan sistem penyelenggaraan negara itu juga pada dasarnya diperuntukkan bagi seluruh rakyat itu sendiri, istilah Inggris menyebutnya "the government of the people, bye the people and for the people". Bahkan, negara yang baik diidealkan juga agar diselenggarakan bersama-sama dengan rakyat dalam arti dengan melibatkan seluruh masyarakat dalam arti seluas-luasnya.

Ditinjau dari perkembangan teori maupun praktik, demokrasi terus berkembang, sehingga tepatlah apa yang dikemukakan Manan bahwa demokrasi merupakan suatu fenomena yang tumbuh, bukan suatu penciptaan. ${ }^{10}$ Oleh karena itu, praktik demokrasi di setiap negara tidaklah selalu sama. Walaupun demikian,

${ }^{6}$ David Held, Models of Democracy, diterjemahkan oleh Abdul Haris, Akbar Tandjung Institute, Jakarta, 2007, hlm. xxiii. Dalam Ni'matul Huda, Ilmu Negara, Cet 1, Rajawali Pers, Jakarta, 2010. hlm.195.

7 Jimly Asshiddiqie, Konstitusi dan Konstitusionalisme Indonesia, Sekretariat Jenderal dan Kepaniteraan MK RI, Jakarta, 2006. hlm.140

${ }^{8}$ Ibid.

${ }^{9}$ Ni'matul Huda, Hukum Tata Negara Indonesia. PT Raja Grafindo Persada, Jakarta, 2006, hlm. 241

10 Abdul Latif, Fungsi Mabkamah Konstitusi: Upaya Mewujudkan Negara Hukum Demokrasi, Cet 2, Total Media, Jakarta, 2009, hlm. 28. 
Liyphard mengatakan bahwa sebuah negara dapat dikatakan demokrasi paling tidak harus memenuhi unsur-unsur sebagai berikut:11

1) Ada kebebasan untuk membentuk dan menjadi anggota perkumpulan;

2) Ada kebebasan menyampaikan pendapat;

3) Ada hak untuk memberikan suara dalam pemungutan suara;

4) Ada kesempatan untuk dipilih atau menduduki berbagai jabatan pemerintah atau negara;

5) Ada hak bagi para aktivis politik berkampanye untuk memperoleh dukungan atau suara;

6) Ada pemilihan yang bebas dan jujur;

7) Terdapat berbagai sumber informasi;

8) Semua lembaga yang bertugas merumuskan kebijakan pemerintah harus bergantung kepada keinginan rakyat.

Selain itu, Sargent menyatakan bahwa unsur-unsur yang juga harus dipenuhi negara demokrasi adalah: 1) citizen invocvement in poltical decision making; 2) some degree of equality among citizens; 3) some degree of liberty or freedom granted to or retained by citizens; 4) a system of representation; dan 5) an electoral system majority role. 12

Untuk membentuk pemerintahan yang demokratis dalam suatu negara demokrasi diperlukan institusionalisasi nilai demokrasi yang substansial menjadi nilai yang terlembagakan. Nilai yang terlembagakan inilah yang oleh para pakar ilmu politik disebut demokrasi procedural. Demokrasi procedural mengharuskan adanya pemilu sebagai salah satu ruang bagi warga negara berkontestasi dan berkompetisi secara sehat dalam pemerintahan. Pemilu menjadi tanda jaminan terhadap hak individu, kebebasan perorangan, partisipasi publik, dan kesadaran hak berpolitik warga negara dalam bentuk keterlibatan yang aktif untuk memilih wakil-wakil di parlemen. ${ }^{13}$

Namun, yang perlu ditekankan adalah bahwa pemilu bukanlah sekedar prosedur mengabsahkan kekuasaan belaka. Pemilu memiliki implikasi yang sangat luas, lebih dari sekedar pergantian atau pembentukan kekuasaan, yaitu pada perubahan kehidupan masyarakat yang lebih baik dan lebih demokratis, pada tata kelola pemerintahan yang baik dan tentunya pemerintahan yang bersih.

\footnotetext{
${ }^{11}$ Ibid.

${ }^{12}$ Ibid., hlm. 29

${ }^{13}$ Ibid.
} 
Oleh karena itu, pemilu tidaklah sekedar prosedural, akan tetapi pemilu haruslah demokratis. ${ }^{14}$

Secara normatif, ada sejumlah persyaratan untuk mewujudkan pemilu yang demokratis, antara lain yaitu: 15

1) Ada pengakuan terhadap hak pilih universal. Semua warga negara, tanpa pengecualian yang bersifat ideologis dan politis, diberi hak untuk memilih dan dipilih dalam pemlu;

2) Ada keleluasaan untuk membentuk "tempat penampungan" bagi pluralitas aspirasi masyarakat pemilih. Masyarakat memiliki alternatif pilihan saluran aspirasi politik yang leluasa. Pembatasan jumlah kontestan Pemilu yang mempertimbangkan alasan yuridis formal dengan menafikkan perkembangan real aspirasi masyarakat adalah sebuah penyelewengan prinsip ini;

3) Tersedia mekanisme rekrutmen politik bagi calon-calon wakil rakyat yang demokratis;

4) Ada kebebasan bagi pemilih untuk mendiskusikan dan menentukan pilihan;

5) Ada komite atau panitia pemilihan yang independen;

6) Ada keleluasaan bagi setiap kontestan untuk berkompetisi secara sehat;

7) Penghitungan suara yang jujur;

8) Netralis birokrasi.

Dalam hal tanggungjawab negarapun, terdapat beberapa hal yang juga tidak dapat diabaikan dalam mewujudkan pemilu yang demokratis. Beberapa hal tersebut yakni16:

1) Negara harus mengambil langkah-langkah legislatif dan tindakan lain yang diperlukan sesuai dengan proses konstitusionalnya untuk menjamin hak-hak dan kerangka konstitusional untuk pemilu yang periodik, murni, bebas dan adil, semua dengan kewajibannya menurut UU Internasional, yang meliputi: menyusun sebuah prosedur yang efektif, tidak memihak dan tidak diskriminatif untuk pendaftaran pemilih; menyusun kriteria yang jelas untuk pendaftaran pemilih menurut usia, kewarganegaraan dan tempat tinggal, serta menjamin bahwa ketentuan itu dilaksanakan tanpa perbedaan apapun; menunjang terbentuknya dan berfungsinya secara bebas partai-partai politik, sedapat mungkin mengatur pembiayaan partai-partai politik dan kampanye Pemilu, menjamin pemisahan antara partai dengan negara dan menciptakan kondisi untuk persangan dalam pemilihan legislatif atas dasar persamaan derajat;

2) Mengambil kebijakan dan langkah-langkah institusional guna kemajuan pencapaian dan konsolidasi cita-cita demokratis, termasuk pembentukan

14 Sri Hastuti Puspitasari, Mewujudkan Pemilu yang Demokratis dan Berkualitas, Proshiding Seminar Nasional Instrumen Hukum Pencegahan dan Penindakan Praktik Money Politics dalam Pemilu 2014, PSHK, Yogyakarta, 2014, hlm. 97

${ }^{15}$ Ibid.

16 Ibid., hlm. 99-100 
mekanisme yang netral dalam penyelenggaraan pemilu, yang mencakup: tanggungjawab menyediakan tenaga terlatih dan tidak memihak, serta prosedur pemilu yang diberitahukan kepada masyarakat; menjamin pemungutan suara; mendorong partai-partai, para calon dan media untuk menjalankan code of conduct (kode etik) untuk mengatur kampanye pemilu dan pemungutan suara; menjamin integritas kotak suara melalui langkah-langkah tepat untuk mencegah pemberian suara ganda, atau pemberian suara oleh mereka yang tidak berhak; menjamin integritas proses perhitungan suara;

3) Negara harus menghormati dan menjamin hak asasi setiap orang dan harus tunduk pada perundang-undangannya;

4) Negara harus menjamin prinsip percobaan secara rahasia, pemilih dapat memberikan suaranya dengan bebas, tanpa rasa takut atau intimidasi;

5) Negara harus menjamin pencoblosan secara rahasia, pemilih dapat memberikan suaranya dengan bebas, tanpa rasa takut atau intimidasi;

6) Negara harus menjamin pencoblosan terhindar dari pemalsuan dan hal-hal yang tidak sah, perhitungan suara dilakukan oleh tenaga telatih, boleh dipantau dan/atau diverifikasi secara adil;

7) Negara menjamin transparansi dari seluruh proses pemilu;

8) Negara menjamin bahwa partai-partai dan para calon serta para pendukung memperoleh pengalaman bersama, negara harus mencegah terjadinya kekerasan dalam pemilu;

9) Negara menjamin bahwa pelanggaran hak asasi dan segala pengaduan berkaitan dengan proses pemilu ditangani segera dalam periode proses pemilu dan secara efektif oleh lembaga independen yang tidak memihak, seperti komisi pemilu atau pengadilan.

Melihat hal tersebut, maka menjadi benar pendapat Merloe yang menggolonglan pemilu demokratis haruslah mencakup 3 hal penting, yaitu: 1) ada tidaknya pengakuan, perlindungan, dan pemupukan Hak Asasi Manusia (HAM); 2) terdapat persaingan yang adil dari peserta pemilu; 3) terbangunnya kepercayaan masyarakat terhadap pemilu yang menghasilkan pemerintahan yang legitimate. Ketiga hal ini merupakan satu kesatuan yang tidaklah dapat dipisahkan untuk mewujudkan demokrasi dan pemilu yang demokratis. ${ }^{17}$

\section{Urgensi Dilakukan Redesain terhadap Kewenangan Mahkamah Konstitusi}

Pemilu memainkan peran yang sangat penting sebagai sebuah pranata dalam setiap negara demokrasi. Sebagai salah satu mekanisme kelembagaan demokrasi, sistem pemilu merupakan wahana yang dapat dengan mudah

${ }^{17}$ Muktie Fadjar, Pemilu Perselisihan Hasil Pemilu dan Demokrasi, Setara Press, Malang, 2003, hlm. 28 
dimanipulasi. Artinya sistem pemilihan bisa dirancang untuk memperlancar perilaku politik tertentu, dan sebaliknya menciptakan hambatan guna melemahkan kekuatan politik lain. Oleh karenanya, menjadi penting untuk menyelenggarakan pemilu secara demokratis.

Mukthie Fadjar mengatakan, bahwa perwujudan pemilu yang demokratis tidak cukup hanya dengan dipenuhinya atribut-atribut formal demokrasi, seperti adanya lembaga perwakilan, adanya lebih dari satu partai politik yang bersaing dalam pemilu, dan adanya pemilu yang periodik. Pemilu yang demokratis juga bukan hanya sekedar lambang, tapi pemilu yang demokratis haruslah kompetitif, berkala, inklusif (luas), dan definitif. ${ }^{18}$ Demokrasi dan proses demokratisasi pemilu harus didasarkan pada standar-standar Hak Asasi Manusia (HAM) agar lebih bermakna partisipatoris dan emansipatoris. Sebab jika tidak, demokrasi akan mudah dikooptasi dan diselewengkan. ${ }^{19}$

Namun, pertanyaannya kini adalah apakah pemilu yang selama ini berlangsung di Indonesia terlebih khusus pemilu Presiden dan Wakil Presiden telah berjalan secara demokratis? Pertanyaan ini menjadi penting untuk dijawab, sebab bagaimanapun mewujudkan pemilu yang demokratis merupakan suatu kewajiban bagi sebuah negara demokrasi.

Cara sederhana yang kemudian dapat digunakan untuk mengukur demokratis atau tidaknya suatu penyelenggaraan pemilu adalah melalui electoral laws dan electoral procces dari pelaksanaan pemilu itu sendiri. Berkaitan dengan electoral laws, pemilu dapat dikatakan demokratis apabila peraturan penyelenggaraan pemilu tidak bertentangan dengan UUD NRI 1945, sedangkan dalam hal electoral proccess, pemilu dapat dikatakan demokratis apabila tidak terjadi pelanggaran dan permasalahan terhadap hasil daripada pelaksanaan pemilu itu sendiri. Kalaulah kemudian terjadi kemungkinan adanya pelanggaranpelanggaran pemilu dan perselisihan hasil pemilu, tersedia mekanisme hukum yang dapat digunakan agar mampu menyelesaikan permasalahan tersebut secara demokratis dan proporsional. 
Berbicara mengenai mekanisme penyelesaian, di Indonesia lembaga yang diberi kewenangan untuk menjalankan fungsi penyelesaian terhadap sengketa perselisihan hasil pemilu adalah Mahkamah Konstitusi, sebagaimana ditentukan dalam Pasal 24 C ayat (4) UUD NRI 1945. Namun sangat disayangkan, selama perjalanannya masih terdapat permasalahan berkenaan dengan electoral process pada diri MK dalam penyelesaian pelanggaran penyelenggaraan pemilu. Hal tersebut membuat MK belum mampu memainkan perannya dengan baik dalam menyelesaikan perselisihan hasil pemilu, terlebih khusus adalah pemilu Presiden dan Wakil Presiden. Hal tersebut juga membuat pemilu yang berlangsung di Indonesia kini belum sepenuhnya berjalan secara demokratis.

Secara ideal, penyelesaian perselisihan hasil pemilu semestinya menawarkan harapan pada perubahan terhadap keadaan yang membosankan dan melelahkan. Hal tersebut sangat tergantung pada perangkat, proses dan mekanisme pelaksanaan yang niscaya berpengaruh terhadap hasil. Sudah saatnya kini kita sadar bahwa pemilu yang demokratis tercermin dalam electoral laws dan electoral process-nya. Jika MK telah dapat menentukan apakah suatu ketentuan electoral laws demokratis atau tidak melalui uji konstitusional UU pemilu terhadap UUD NRI 1945, maka sudah semestinya MK juga mampu berperan dengan baik dalam hal electoral process melalui peradilan perselisihan hasil pemilu guna menggali sedalam-dalamnya keadilan pada proses pelaksanaan pemilu yang dilakukan oleh KPU.

Itulah sebabnya kenapa kemudian menjadi penting untuk dilakukannya redesain terhadap kewenangan MK dalam hal penyelesaian perselisihan hasil pemilihan umum Presiden dan Wakil Presiden. Mendesain kembali konsep penyelesaian perselisihan hasil pemilu dimaksudkan sebagai bentuk ikhtiar menemukan alternatif solusi terhadap perselisihan hasil pemilu yang dapat memberikan rasa kepastian hukum, keadilan dan kemanfaatan bagi yang berselisih ataupun pihak lain yang terkait yakni masyarakat.

Proses penyelesaian perselisihan hasil pemilu yang ideal di MK pada hakekatnya ditujukan untuk melindungi dan memperjuangkan hak-hak konstitusional semua pihak yang terlibat, sebagaimana diamanatkan dalam Pasal 1 ayat (2) UUD NRI 1945 yang menyatakan bahwa "Kedaulatan berada di tangan 
rakyat dan dilaksanakan menurut Undang-Undang Dasar". Dengan kata lain, tujuannya adalah untuk memastikan bahwa hak atas konversi suara oleh rakyat dapat terlaksana secara adil dan tidak terlanggar dengan maraknya tindakan manipulatif oleh peserta pemilu.

Jauh lebih penting dari hal tersebut adalah bagaimana mekanisme penyelesaian perselisihan hasil pemilu yang ideal mampu mengembalikan suara rakyat yang telah terkonversi kepada pihak yang berhak, sesuai dengan kehendak rakyat yang sesungguhnya. Apabila proses penyelesaian tersebut belum mampu berjalan secara efektif, tentu berimplikasi pada tidak terlindunginya hak-hak para pihak yang terlibat dalam proses pemilu. Selain itu, upaya redesain tersebut dalam rangka mewujudkan kembali semangat reformasi, yakni mendemokratiskan pemilu. Pemilu yang demokratis di negara demokrasi menjadi sangat penting mengingat tujuan pemilu itu sendiri.

Sebagai upaya mewujudkan pemilu yang demokratis dan terciptanya penyelesaian perselisihan hasil pemilu yang dapat memberikan rasa kepastian hukum, keadilan dan kemanfaatan bagi semua pihak, maka redesain terhadap kewenangan MK dalam hal penyelesaian perselisihan hasil pemilu terlebih khusus adalah pemilu Presiden dan Wakil Presiden sudah tidak dapat ditawar lagi. Karena dengan inilah Indonesia dapat menguatkan eksistensinya sebagai negara demokrasi. Hal ini mengingat bahwa bagaimanapun tolak ukur keberhasilan dari sebuah negara demokrasi adalah ketika negara tersebut mampu menyelenggarakan proses pemilu secara demokratis.

\section{Konsep Ideal Penyelesaian Sengketa Perselisihan Hasil Pemilihan Umum Presiden dan Wakil Presiden Indonesia}

Berdasarkan pengamatan dan pengkajian yang dilakukan, didapatlah kesimpulan bahwa menjadi penting untuk dilakukannya redesain terhadap kewenangan MK dalam penyelesaian sengketa PHPU Presiden dan Wakil Presiden di Indonesia dalam rangka mewujudkan pemilu yang demokratis dan terciptanya penyelesaian perselisihan hasil pemilu yang dapat memberikan rasa kepastian hukum, keadilan dan kemanfaatan bagi semua pihak. Beberapa hal yang perlu diredesain tersebut meliputi: 


\section{Pertama: Perluasan makna hasil pemilu yang demokratis}

Semangat reformasi untuk mendemokratiskan pemilu dalam perjalanannya kini mengalami beberapa hambatan. Salah satu hambatan yang dimaksud adalah belum terinternalisasikannya semangat reformasi tersebut dalam electoral procces dari pelaksanaan pemilu itu sendiri. Hal ini terlihat jelas dengan terbatasanya ruang gerak MK dalam menggali keadilan pada proses penyelesaian sengketa perselisihan hasil pemilu, terlebih khusus pada pemilu Presiden dan Wakil Presiden.

Pasal 24 C ayat (4) UUD NRI 1945 menyebutkan antara lain MK memiliki kewenangan dalam menyelesaikan sengketa perselisihan hasil pemilu. Namun permasalahannya, ketentuan yang menjadi dasar kewenangan MK tersebut tidak memberikan pemahaman yang jelas mengenai maksud perselisihan hasil pemilu. Pemahaman kemudian coba dibangun melalui ketentuan Pasal 77 UU No. 24 Tahun 2003 tentang MK. Di dalam ketentuan tersebut, perselisihan hasil pemilu diartikan secara sempit, yakni hanya sebagai perselisihan hasil pemilu yang ditetapkan secara nasional oleh KPU.

Sempitnya pemaknaan hasil pemilu tersebut membuat MK kini "tersandera" dalam menjalankan tugasnya sebagai the guardian of the democracy. Implikasinya adalah MK kini disebut sebagai "Mahkamah Kalkulator" karena dalam menyelesaikan sengketa PHPU, MK hanya dibatasi untuk menilai benar atau tidaknya perhitungan suara yang telah ditetapkan secara nasional oleh KPU dan tidak lebih dari itu.

Kendati demikian, jika kita mencermati perjalanan MK dalam menyelesaikan sengketa PHPU selama ini (Pemilu Legislatif, Kepala Daerah serta Presiden dan Wakil Presiden), menarik untuk dicermati bahwa sebenarnya MK pernah melakukan terobosan hukum melalui tindakan judicial activism dengan memutus sebuah perkara PHPU melebihi mandat yang diberikan kepadanya. Dengan kata lain, MK pernah melakukan pergeseran konsep perselisihan hasil pemilu tidak sekedar berkutik pada perselisihan "jumlah suara yang diperoleh peserta pemilihan umum" saja, namun ke arah yang lebih substansial dari hal tersebut. Sebagai contoh putusan MK pada Pemilukada Jawa Timur di 2008, 
Pemilukada Bengkulu Selatan pada 2009, Pemilukada Tebing Tinggi pada 2010, Pemilukada Mandailing Natal pada 2010, dan Pemilukada Kotawaringin Barat pada $2010 .{ }^{20}$

Namun sangat disayangkan, ketika tindakan judicial activism yang dilakukan oleh MK tersebut menuai banyak kritik. Salah satu kritik yang muncul adalah ketika MK memutus sebuah perkara melebihi mandat yang diberikan kepadanya. Para ahli dan akademisi mempersoalkan bahwa dalam perselisihan hasil pemilu, mandat yang diberikan kepada MK hanyalah masalah sengketa perolehan suara, lebih spesifik lagi perolehan suara yang mempengaruhi hasil pemilu. Masalah-masalah yang terkait dengan proses pemilu menjadi tanggungjawab peradilan lain untuk memutuskannya. ${ }^{21}$

Secara yudiris, penulis mengamini kritikan yang muncul terhadap MK karena tindakan judicial ativism yang dilakukannya. Karena undang-undangpun memerintahkan MK untuk menyelesaikan sengketa PHPU hanya sebatas hasil perhitungan yang diumumkan secara nasional oleh KPU. Namun demikian, penulis beranggapan bahwa pelanggaran-pelanggaran yang menyebabkan terjadinya hasil perhitungan suara yang kemudian dipersengketakan tersebut harus pula dinilai untuk menegakkan keadilan, terlebih pelanggaran tersebut bersifat terstruktur, sistematis dan masif. Hal ini sejalan dengan semangat pembentukan Pasal 24 ayat (1) UUD NRI 1945 yang berbunyi: "Kekuasaan kehakiman merupakan kekuasaan yang merdeka untuk menyelenggarakan peradilan guna menegakkan hukum dan keadilan," dan Pasal 28 D ayat (1) UUD NRI 1945 yang berbunyi: "Setiap orang berhak atas pengakuan jaminan, perlindungan dan kepastian hukum yang adil serta perlakuan yang sama di depan hukum". Ditambahkan lagi John Rawls pernah berkata dalam bukunya yang berjudul “Teori Keadilan”, bahwa keadilan adalah kebajikan utama dalam institusi sosial, sebagaimana kebenaran dalam sistem pemikiran. ${ }^{22}$

20 Lihat beberapa Putusan MK tentang sengketa PHPU Pilkada (Putusan Nomor 41/PHPU.D.VI/2008, Diputus pada tanggal 2 Desember 2008; Putusan Nomor 57/PHPU.D.VI/2008, Diputus pada tanggal 8 Januari 2009; Putusan Nomor 12/PHPU.D.VIII/2010, Diputus pada tanggal 9 Juni 2010; Putusan Nomor; 41/PHPU.D.VIII/2010, Diputus pada tanggal 6 Juli 2010; dan Putusan Nomor 45/PHPU.D.VIII/2010, Diputus pada tanggal 7 Juli 2011)

${ }^{21}$ Refly Harun, "Rekonstruksi Kewenangan Mabkamah Konstitusi dalam Menangani Perselisihan Hasil Pemilu", artikel pada Majalah Hukum, edisi no.341, 2014, hlm. 52

22 John Rawls, Teori Keadilan (terjemahan), Pustaka Pelajat, Yogyakarta, 2006, hlm. 3 
Berkaitan dengan apa yang disampaikan oleh Rawls tersebut, sebagai peradilan konstitusi, MK pada prinsipnya tidak boleh membiarkan aturan-aturan keadilan procedural justice (prosedural) memasung dan mengesampingkan keadilan subtantif (subtantive justice). Hal ini karena bagaimanapun fakta-fakta hukum yang terungkap dalam sengketa PHPU secara nyata merupakan pelanggaran konstitusional, khususnya melanggar asas-asas pemilu. Satu prinsip hukum dan keadilan yang dianut secara universal menyatakan bahwa "...nullus/nemo commodum capere potest de injuria sua propria", yang artinya tidak seorang pun boleh diuntungkan oleh penyimpangan dan pelanggaran yang dilakukan sendiri dan tidak seorang pun boleh dirugikan oleh penyimpangan dan pelanggaran yang dilakukan oleh orang lain. ${ }^{23}$ Dengan kata lain, tidak satu pun pasangan calon Presiden dan Wakil Presiden yang boleh diuntungkan dalam perolehan suara akibat pelanggaran terhadap asas-asas pelaksanaan pemilu dan prinsip keadilan dalam penyelenggaraan pemilu.

Selain itu, dalam putusan No. 190/PHPU.D-VIII/2010 MK pun juga telah menegaskan bahwa:

"pembatalan hasil pemilu atau pemilukada karena pelanggaran-pelanggaran yang bersifat terstruktur, sistematis dan masif sama sekali tidak dimaksudkan oleh MK untuk mengambil alih kewenangan badan peradilan lain. Mahkamah tidak akan pernah mengadili pelanggaran pidana dan administrasi dalam pemilu dan pemilukada, melainkan hanya mengambil pelanggaran-pelanggaran yang terbukti di bidang itu yang berpengaruh terhadap hasil pemilu dan pemilukada sebagai dasar putusan, tetapi tidak menjatuhkan sanksi pidana dan administrasi terhadap pelakunya"24

Menilik hal tersebut, memandang perlu menciptakan terobosan hukum guna mewujudkan demokratisasi pemilu dan melepaskan diri dari kebiasaan praktik pelanggaran yang terstruktur, sistematis dan masif. Karena betapapun elegan dan ekonomisnya suatu teori, tetap harus ditolak atau direvisi jika teori tersebut tidak benar. Demikian juga hukum dan institusi, tidak peduli betapa efisien dan rapinya, harus direformasi atau dihapuskan jika tidak adil. ${ }^{25}$

Untuk itu, sudah saatnya kini kita menganggap bahwa larangan bagi MK dalam menangani berbagai kasus pelanggaran yang terjadi pada proses

\footnotetext{
23 Paragraf 3.27.10 Putusan Nomor 1/PHPU.PRES-XII/2014

24 Putusan Nomor 190/PHPU.D-VIII/2010

${ }^{25}$ John Rawls, Op.Cit., hlm. 3
} 
perselisihan hasil pemilu diartikan bahwa MK tidak boleh melakukan fungsi peradilan pidana ataupun peradilan administrasi, namun tetap boleh mempermasalahkan dan mengadili setiap pelanggaran yang berakibat pada hasil perhitungan suara. Sudah saatnya pula dilakukan pergeseran makna terhadap kewenangan MK dalam menangani sengketa hasil pemilu. Ketika sebelumnya kewenangan dalam menangani sengketa hasil pemilu dimaknai hanya sebatas pada perhitungan suara pemilu saja, kini sengketa hasil pemilu harus dimaknai sebagai segala bentuk kecurangan yang melanggar asas langsung, umum, bebas, rahasia, jujur dan adil. Dengan kata lain, MK sebagai the guardian of the democracy diberikan kewenangan yang lebih subtantif untuk menjaga pemilu sesuai dengan asas langsung, umum, bebas, rahasia, jujur dan adil.

Bagaimanapun, hakekat pemilu bukanlah semata-mata dalam rangka mencapai tujuan untuk mendapatkan dukungan dan legitimasi rakyat semata, tetapi pemilu harus pula melalui prosedur dan tata cara yang ditentukan oleh hukum yang berlaku. Dalam demokrasi, antara tujuan dan tata cara adalah dua sisi yang tidak bisa diabaikan. Prosedur dan tata cara justru memberi jaminan tegaknya prinsip demokrasi yang memberikan jaminan atas persamaan hak, kesetaraan dan kebebasan itu sendiri. Itulah sebabnya UUD NRI 1945 dalam Pasal 22 E ayat (1) menentukan dengan tegas mengenai asas penyelenggaraan pemilu yang harus ditaati dalam setiap penyelenggaraannya.

Kedua: Desain tolak ukur pelanggaran yang bersifat Terstruktur, Sistematis, dan Masif (TSM) dalam sengketa PHPU Presiden dan Wakil Presiden

Perlu diketahui bahwa tidak semua pelanggaran pemilu dapat membatalkan hasil pemilihan umum yang telah dilaksanakan. Pelanggaran pemilu yang dapat membatalkan hasil pemilihan umum hanyalah pelanggaran yang nyata-nyata terbukti memenuhi unsur terstruktur, sistematis dan masif. Kesalahan prosedural yang bersifat teknis administratif, ataupun pelanggaran pemilu yang dilakukan tanpa adanya perencanaan secara terstruktur serta tidak berdampak secara luas merupakan "pelanggaran pemilu biasa" yang tidak dapat dikategorikan sebagai pelanggaran pemilu yang bersifat TSM. Pelanggaran yang 
demikian, menurut cukup diproses dan diselesaikan oleh lembaga peradilan yang berwenang untuk itu. ${ }^{26}$

Lebih lanjut, berkaitan dengan sifat terstruktur, sistematis dan masif dalam pelanggaran pemilu, Manuar Siahaan (mantan hakim konstitusi) ${ }^{27}$ menjelaskan bahwa sifat struktur dapat diartikan sebagai pelanggaran yang dilakukan dalam struktur pemerintahan atau struktur partai politik dari tatanan tertinggi sampai terendah untuk memenangkan salah satu pasangan calon. Sistematis diartikan sebagai suatu sistem yang dirancang dengan matang. Sedangkan masif berarti dilakukan di wilayah luas dan komprehensif di seluruh kecamatan di daerah yang menjadi objek pemilu secara merata.

Selain itu, menurut Mukhtie Fadjar (mantan hakim konstitusi), ${ }^{28}$ pelanggaran pemilu yang bersifat sistematis, terstruktur dan masif merupakan pelanggaran-pelanggaran yang memang direncanakan sejak semula, baik oleh negara, penyelenggara pemilu maupun peserta pemilu, bersifat meluas dan benar-benar merusak sendi-sendi Pemilu yang 'luber' dan 'jurdil'.

Jika pendapat 2 mantan hakim konstitusi tersebut dikaitkan dengan kajian terhadap 2 putusan MK yang telah diuraikan sebelumnya, maka benang merahnya adalah pelanggaran pemilu Presiden dan Wakil Presiden dapat dikatakan bersifat terstruktur, sistematis, dan masif ketika pelanggaran tersebut dilakukan oleh aparat struktural, baik aparat pemerintah maupun aparat penyelenggara pemilu secara kolektif, benar-benar direncanakan secara matang dan berdampak sangat luas, bukan sporadis, serta terjadi secara merata di hampir semua wilayah yang menjadi cakupan dari penyelenggaraan pemilu itu sendiri. Selain itu, dapat disimpulkan pula bahwa TSM adalah satu kesatuan unsur yang tidaklah dapat dipisahkan. Artinya, MK hanya dapat membatalkan hasil pemilu apabila unsur tersebut terpenuhi secara kumulatif di dalam fakta persidangan.

Tolak ukur inilah yang kemudian dapat digunakan hakim konstitusi dalam memutus sengketa PHPU Presiden dan Wakil Presiden kedepannya. Agar

\footnotetext{
26 Kajian terhadap Putusan Mahkamah Konstitusi Nomor 108-109/PHPU.B-VII/2009 dan Putusan Mahkamah Konstitusi Nomor 1/PHPU.PRES-XII/2014

27 Lihat dalam "Daftar Putusan MK tentang Perselisihan Hasil Pemilukada (sepanjang Maret 2011)," Majalab Konstitusi No. 50-Maret 2-11, hlm. 64. Dalam Ni'matul Huda, Dinamika Ketatanegaraan Indonesia dalam Putusan Mabkamah Konstitusi, FH UII Press, Yogyakarta, 2011, hlm. 211

28 Ibid
} 
kemudian tafsir tersebut tidak "liar", maka menjadi penting penafsiran tersebut diregulasikan ke dalam undang-undang yang mengatur tentang penyelenggaraan pemilu Presiden dan Wakil Presiden. Ketika tafsir tersebut tertuliskan secara jelas di dalam undang-undang, setidaknya hakim konstitusi memiliki parameter yang pasti untuk menentukan apakah pelanggaran pemilu tersebut hanyalah pelanggaran pemilu biasa ataukah pelanggaran pemilu yang bersifat TSM sehingga dapat membatalkan hasil pemilu yang dilakukan sebelumnya.

\section{Ketiga: Desain waktu persidangan dalam penyelesaian sengketa PHPU Presiden dan Wakil Presiden}

Berkenaan dengan waktu penyelesaian sengketa, Pasal 11 ayat (1) Peraturan Mahkamah Konstitusi menyebutkan: "Pemeriksaan perkara perselisihan hasil Pemilu Presiden dan Wakil Presiden diputus paling lambat 14 (empat belas) hari kerja sejak permohonan dicatat dalam Buku Registrasi Perkara Konstitusi". Tidak ditemukan alasan yang jelas mengenai adanya pembatasan waktu di dalam ketentuan tersebut. Namun menurut hemat penulis, hal itu didasari oleh pertama, guna mengakomodir jadwal rangkaian dalam pemilu yang padat dan sudah terjadwal. Maka sesuai dengan jadwal tahapan yang telah di desain KPU, perkara PHPU Presiden di MK dilakukan secara cepat (speedy trial) untuk menghindari kekacauan serta pemanfaatan pihak tertentu untuk mengulur waktu; kedua dilakukan untuk menghindari kekosongan jabatan Presiden, karena kekosongan pemimpin akan melahirkan krisis konstitusional. Akan tetapi pertanyaan yang kemudian muncul adalah apakah tepat keputusan pembuat peraturan dengan memberikan batasan waktu 14 hari bagi MK dalam menyelesaikan perselisihan hasil pemilu Presiden dan Wakil Presiden tersebut?

Berkaitan dengan hal tersebut, Ni'matul Huda mengatakan bahwa pembatasan waktu yang diberikan kepada MK untuk menyelesaikan sengketa PHPU Presiden dan Wakil Presiden membuat perkara tersebut yang idealnya bukan perkara yang sederhana dalam arti tingkat kompleksitas masalahnya, terkesan menjadi perkara yang sederhana. ${ }^{29}$ Selain itu, pakar hukum tata negara

${ }^{29}$ Ni’matul Huda, Penyelesaian Sengketa Pemiliban Umum 2014 di Mabkamah Konstitusi, Proshiding Seminar dan Lokakarya Evaluasi Penyelenggaraan Pemilihan Umum Legislatif Tahun 2014 di Indonesia, PSHK, Yogyakarta, 2014, hlm. 90 
lainnya pun berpendapat yang tidak jauh berbeda. Refly Harun mengatakan bahwa: ${ }^{30}$

Mahkamah Konstitusi (MK) diharapkan tidak lagi disulitkan dengan waktu yang terbatas untuk menelusuri bukti dari tingkat bawah. Dalam 14 hari, tidak cukup waktu untuk menangani seluruh kasus yang buktinya C1 palsu, mendatangkan saksi-saksi dari tingkat PPS dan PPK. Jika hal tersebut terus dilakukan pada pemilu Presiden, maka besar kemungkinan MK akan memutuskan sendiri dengan bukti seadanya. Pada pengalaman pemilu legislatif yang lalu, hal tersebut tidak efektif, karena waktu tidak cukup hanya 14 hari.

Pendapat kedua pakar hukum tata negara tersebut menjadi relevan mengingat bahwa perkara perselisihan hasil Pemilu Presiden memang bukanlah perkara yang sederhana. Kompleksitas permasalahan yang timbul seharusnya mampu diselesaikan dengan kepala dingin oleh seluruh hakim konstitusi dan tentunya tidak terlalu terikat oleh waktu yang bisa dikatakan tidak begitu ideal. Ditambah lagi kini MK dengan konsep baru yang penulis tawarkan, dituntut untuk memeriksa perkara tidak hanya sebatas selisih perolehan suara yang ditetapkan secara nasional oleh KPU, melainkan juga memeriksa seluruh pelanggaran pemilu yang bersifat terstruktur, sistematis dan masif yang jelas melanggar asas-asas pemilu itu sendiri. Untuk itu, meninjau kembali pembatasan waktu tersebut menjadi penting untuk dilakukan.

Setidaknya ada beberapa hal yang dapat dijadikan pertimbangan dalam menentukan kembali waktu ideal bagi MK dalam menyelesaikan sengketa PHPU Presiden dan Wakil Presiden, pertama, cakupan pelaksanaan pemilu Presiden dan Wakil Presiden meliputi seluruh Provinsi di Indonesia. Sehingga bukan tidak mungkin permasalahan yang timbul juga dari seluruh Provinsi yang dimaksud. Implikasinya adalah proses pengumpulan alat bukti, pemeriksaan alat bukti hingga pembuktian di dalam persidangan akan memerlukan waktu yang ekstra; kedua, MK kini dituntut untuk memeriksa bukan hanya mengenai selisih perhitungan suara, namun memeriksa kearah yang lebih subtantif (mengenai asas LUBER JURDIL); ketiga, proses penyelesaian perselisihan hasil pemilu di MK pada hakekatnya ditujukan untuk melindungi dan memperjuangkan hak-hak konstitusional semua pihak yang terlibat, sehingga atas hal tersebut MK dituntut

30 http://www.solopos.com/2014/07/13/hasil-pilpres-2014-penyelesaian-sengketa-pemilu-presidendiharapkan-lebih-baik-519105 [Diakses pada 27 Februari 2015] 
agar mampu memeriksa seluruh alat bukti secara cermat dan seksama; dan keempat, pertimbangan mengenai terjadinya kekosongan hukum yang akan terjadi jika proses penyelesaianpun tidak dibatasi waktu atau waktu yang diberikan kepada MK juga dirasa terlalu lama.

Pertimbangan-pertimbangan tersebut membuat penulis berkesimpulan bahwa dalam mendesain ulang waktu penyelesaian sengketa PHPU Presiden dan Wakil Presiden, harus benar-benar dilakukan secara cermat pula. Waktu 14 hari yang diberikan kepada MK kini harus ditambah, namun tetap harus ada pembatasan dan berdasarkan pada koridor yang berlaku agar tidak menimbulkan kekosongan hukum dikemudian hari.

Mencermati hal tersebut, penambahan waktu yang dirasa ideal adalah 7 hari kerja terhitung sejak berakhirnya waktu 14 hari yang diberikan kepada MK sebelumnya. Artinya, MK tidak hanya "tersandera" untuk menyelesaikan perkara dalam waktu maksimal 14 hari saja. MK dapat menambahnya sehingga pemeriksaan dapat dilakukan lebih bersih, mendetail dan terstruktur. Namun ketika 14 hari tersebut suatu ketika dirasa cukup, maka penambahan waktu 7 hari ini tidak perlu untuk digunakan lagi. Hal ini menurut penulis adalah desain waktu yang ideal mengingat pertimbangan-pertimbangan yang telah diuraikan sebelumnya.

\section{Penutup}

Urgensi dilakukannya redesain terhadap kewenangan MK dalam penyelesaian sengketa PHPU Presiden dan Wakil Presiden di Indonesia adalah dalam rangka mewujudkan kembali semangat reformasi yakni mendemokratiskan pemilu dan juga sebagai bentuk ikhtiar menemukan alternatif solusi terhadap pemilu yang dapat memberikan rasa kepastian hukum, keadilan dan kemanfaatan. Beberapa hal yang perlu didesain tersebut meliputi: pertama, perluasan makna "sengketa hasil pemilihan umum". Pada point ini, perlu dilakukan pergeseran makna terhadap kewenangan MK dalam menangani sengketa hasil pemilu Presiden dan Wakil Presiden. Jika sebelumnya "sengketa hasil pemilu" dimaknai hanya sebatas pada hasil perhitungan suara yang 
ditetapkan secara nasional oleh KPU, namun kini "sengketa hasil pemilu" harus dimaknai sebagai segala bentuk kecurangan yang melanggar asas langsung, umum, bebas, rahasia, jujur dan adil; kedua, mendesain tolak ukur pelanggaran pemilu yang bersifat terstruktur, sistematis dan masif. Berkaitan dengan hal ini, pelanggaran Pemilu Presiden dan Wakil Presiden dapat dikatakan bersifat terstruktur, sistematis, dan masif ketika pelanggaran tersebut dilakukan oleh aparat struktural, baik aparat pemerintah maupun aparat penyelenggara pemilu secara kolektif, benar-benar direncanakan secara matang dan berdampak sangat luas, bukan sporadis, serta terjadi secara merata di hampir semua wilayah yang menjadi cakupan dari penyelenggaraan pemilu itu sendiri. Selain itu, TSM adalah satu kesatuan unsur yang tidak dapat dipisahkan; dan ketiga, mendesain ulang waktu yang diberikan oleh MK dalam menyelesaikan sengketa pemilu. Dalam hal ini, penambahan waktu yang dirasa ideal adalah 7 hari kerja terhitung sejak berakhirnya waktu 14 hari yang diberikan kepada MK sebelumnya. Namun apabila waktu 14 hari suatu ketika dirasa cukup, maka 7 hari tersebut tidak perlu digunakan.

Untuk itu, penulis memberikan saran bagi pemerintah dan Dewan Perwakilan Rakyat (DPR) untuk segera merevisi Undang-Undang Nomor 24 Tahun 2003 Tentang Mahkamah Konstitusi dengan mengakomodir maksud dan arti "sengketa hasil pemilu" yang telah dikonsepkan pada penelitian ini kedalam penjelasan pasal undang-undang tersebut. Selain itu, perlu pula dilakukan revisi terhadap Undang-Undang Nomor 42 Tahun 2008 Tentang Pemilihan umum Presiden berkaitan dengan penambahan waktu pemeriksaan perkara (Pasal 201 ayat (3)) serta dalam rangka mengakomodir mengenai pengertian pelanggaran yang terstruktur, sistematis dan masif dalam undang-undang tersebut. Bagi Mahkamah Konstitusi agar dapat menindaklanjuti materi ketentuan di dalam undang-undang yang akan direvisi kedalam Peraturan Mahkamah Konstitusi berkaitan dengan penyelesaian sengketa hasil pemilu Presiden dan Wakil Presiden. Dan bagi masyarakat agar lebih proaktif dalam membantu mewujudkan pemilu yang demokratis di Indonesia. 


\section{Daftar Pustaka}

\section{Buku-Buku:}

Ashshofa, Burhan, Metode Penelitian Hukum, Cetakan Keempat, Rineka Cipta, Jakarta, 2004.

Asshiddiqie, Jimly, Konstitusi dan Konstitusionalisme Indonesia, Sekretariat Jenderal dan Kepaniteraan MK RI, Jakarta, 2006.

Budiarjo, Miriam, Dasar-Dasar Ilmu Politik, edisi Revisi, PT. Gramedia Pustaka Utama, Jakarta, 2008

Hasan, Iqbal, Pokok-Pokok Mater Metodologi Penelitian dan Aplikasinya, Ghalia Indonesa, Jakata, 2002.

Huda, Ni'matul, Dinamika Ketatanegaraan Indonesia dalam Putusan Mahkamah Konstitusi, FH UII Press, Yogyakarta, 2011. , Hukum Tata Negara Indonesia. PT Raja Grafindo Persada, Jakarta, 2006. Ilmu Negara, Rajawali Press, Yogyakarta, 2010.

Latif, Abdul, Fungsi Mahkamah Konstitusi: Upaya Mewujudkan Negara Hukum Demokrasi, Cet 2, Total Media, Jakarta, 2009.

M. Prijono, Yumiko dan Prijono Tjiptoherijanto, Demokrasi di Pedesaan Jawa, Sinar Harapan, Jakarta, 1983.

Muktie Fadjar, A., Pemilu Perselisihan Hasil Pemilu dan Demokrasi, Setara Press, Malang, 2003.

Rawls, John, Teori Keadilan (terjemahan), Pustaka Pelajar, Yogyakarta, 2006.

Masdar, Umaruddin, Membaca Pikiran Gus Dur dan Amien Rais tentang Demokrasi, Pustaka Pelajar, Yogyakarta, 1999.

Zakaria, Fareed, Masa Depan Kebebasan (Penyimpangan Demokrasi di Amerika dan Negara Lain), PT.INA Republikatama, Jakarta, 2004.

\section{Jurnah dan Makalah Hukum:}

Harun, Refly, "Rekonstruksi Kewenangan Mahkamah Konstitusi dalam Menangani Perselisihan Hasil Pemilu", artikel pada Majalah Hukum, edisi no. 341, 2014, hlm. 48.

Hastuti Puspitasari, Sri, Mewujudkan Pemilu yang Demokratis dan Berkualitas, Proshiding Seminar Nasional Instrumen Hukum Pencegahan dan Penindakan Praktik Money Politics dalam Pemilu 2014, PSHK, Yogyakarta, 2014.

Huda, Ni'matul, Penyelesainan Sengketa Pemilihan Umum 2014 di Mahkamah Konstitusi, Proshidng Seminar dan Lokakarya Evaluasi Penyelenggaraan 
Pemilihan Umum Legislatif Tahun 2014 di Indonesia, PSHK, Yogyakarta, 2014.

\section{Peraturan Perundang-undangan:}

Undang-Undang Nomor 24 Tahun 2003 tentang Mahkamah Konstitusi.

Undang-Undang Nomor 42 Tahun 2008 tentang Pemilihan Umum Presiden dan Wakil Presiden.

Undang-Undang Nomor 8 Tahun 2012 tentang Pemilihan Umum Anggota Dewan Perwakilan Rakyat, Dewan Perwakilan Daerah, Dan Dewan Perwakilan Rakyat Daerah.

\section{Situs Internet:}

http://www.solopos.com/2014/07/13/hasil-pilpres-2014-penyelesaiansengketa-pemilu-presiden-diharapkan-lebih-baik-51910, diakses tanggal 27 Pebruari 2015. 